\title{
The effects of rising atmospheric carbon dioxide on shoot-root nitrogen and water signaling
}

\author{
Hsien Ming Easlon* and Arnold J. Bloom \\ Department of Plant Sciences, University of California at Davis, Davis, CA, USA
}

\section{Edited by:}

Shimon Rachmilevitch, Ben Gurion

University of the Negev, Israel

\section{Reviewed by:}

Louis S. Santiago, University of

California, USA

Roland Pieruschka,

Forschungszentrum Jülich, Germany

\section{*Correspondence:}

Hsien Ming Easlon, Department of Plant Sciences, University of

California at Davis, One Shields

Avenue, Davis, CA 95616, USA

e-mail: heaslon@ucdavis.edu
Terrestrial higher plants are composed of roots and shoots, distinct organs that conduct complementary functions in dissimilar environments. For example, roots are responsible for acquiring water and nutrients such as inorganic nitrogen from the soil, yet shoots consume the majority of these resources. The success of such a relationship depends on excellent root-shoot communications. Increased net photosynthesis and decreased shoot nitrogen and water use at elevated $\mathrm{CO}_{2}$ fundamentally alter these source-sink relations. Lower than predicted productivity gains at elevated $\mathrm{CO}_{2}$ under nitrogen or water stress may indicate shoot-root signaling lacks plasticity to respond to rising atmospheric $\mathrm{CO}_{2}$ concentrations. The following presents recent research results on shoot-root nitrogen and water signaling, emphasizing the influence that rising atmospheric carbon dioxide levels are having on these source-sink interactions.

\section{Keywords: carbon dioxide, nitrogen, nitrate assimilation, water, drought, salinity, chilling}

\section{INTRODUCTION}

Land plants occupy highly dissimilar aboveground and belowground environments and face the basic allocation dilemma of where to invest resources (Bloom et al., 1985). Too little investment in roots leads to nutrient- or water-limited growth, whereas too much investment compromises shoot growth, reproduction, and photosynthesis. Excellent communications between roots and shoots are paramount for meeting the immediate demands of distal organs to optimize resource supply from them, while avoiding superfluous distribution of resources.

For example, the dependence of photosynthesis on nitrogenous compounds and the inevitability of water loss during $\mathrm{CO}_{2}$ uptake (Field and Mooney, 1986) makes communicating $\mathrm{N}$ and water availability from roots to shoots essential to maintain shoot productivity (Boyer, 1982; Bloom, 1997). Conversely, shoot to root communication of leaf $\mathrm{N}$ status is necessary to optimize carbohydrate allocation in roots among growth, $\mathrm{N}$ uptake, and inorganic $\mathrm{N}$ assimilation. Coordination of $\mathrm{N}$ transport from root to shoot and of carbohydrate transport from shoot to root is fundamental for maintaining a $\mathrm{C} / \mathrm{N}$ ratio throughout the plant that is optimal for plant growth and development (Martin et al., 2002; Zheng, 2009).

Climate change, in particular rising $\mathrm{CO}_{2}$, is likely to alter root-shoot communications. Atmospheric $\mathrm{CO}_{2}$ concentrations have remained relatively low, between 180 and $300 \mu \mathrm{mol} \mathrm{mol}^{-1}$ over the last 400,000 years (Petit etal., 1999) and between 140 and $320 \mu \mathrm{mol} \mathrm{mol}{ }^{-1}$ over the last 23 million years (Pearson and Palmer, 2000). Flowering plants have evolved specific adaptations to this low $\mathrm{CO}_{2}$ environment including increased stomatal density (Beerling and Chaloner, 1993), increased leaf vein density (Boyce and Zwieniecki, 2012), and $\mathrm{C}_{4}$ photosynthesis (Ehleringer et al., 1991). This concentration has increased from 280 to $400 \mu \mathrm{mol} \mathrm{mol}^{-1}$ since 1800 from the burning of fossil fuels (Whorf and Keeling, 1998) and is projected to reach between 500 and $900 \mu \mathrm{mol} \mathrm{mol}^{-1}$ by the end of the century (Joos et al., 1999). This $\mathrm{CO}_{2}$ enrichment will increase photosynthesis in $\mathrm{C}_{3}$ plants and will decrease shoot $\mathrm{N}$ and water requirements for photosynthesis. This frequently results in increased biomass and productivity in the short-term that is not sustained in the long-term (Dukes et al., 2005; Korner, 2006; Kimball et al., 2007). Only after long-term growth at elevated $\mathrm{CO}_{2}$ do limitations from $\mathrm{N}$ deficiencies, carbohydrate transport, and altered shoot/root allocation patterns become apparent. Unknown is whether the mechanisms of long distance communication between roots and shoots that evolved under low $\mathrm{CO}_{2}$ will have the plasticity to optimize coordination of root and shoot growth under long-term exposure to elevated $\mathrm{CO}_{2}$.

The goal of this review is to describe shoot-root signaling for $\mathrm{N}$ and water and to examine the observed and predicted responses of these signaling mechanisms to rising atmospheric $\mathrm{CO}_{2}$ concentrations. First, we discuss shoot-root $\mathrm{N}$ signaling, changing $\mathrm{C}$ and $\mathrm{N}$ demand, and the breakdown of $\mathrm{N}$ signaling at elevated $\mathrm{CO}_{2}$. Then, we explore the common and distinctive features of drought, salinity, chilling, and high vapor pressure deficit and the opposing effects of elevated $\mathrm{CO}_{2}$ on chemical and hydraulic water stress signaling. Finally, we consider the effects of non-optimal shoot-root coordination on plant growth at elevated $\mathrm{CO}_{2}$.

\section{NITROGEN: COMMUNICATING ROOT AVAILABILITY AND SHOOT DEMAND}

For most plants, growth and productivity is highly dependent upon $\mathrm{N}$ obtained from root absorption of soil inorganic and organic $\mathrm{N}$. In most temperate soils, the primary form of $\mathrm{N}$ available to plants is nitrate $\left(\mathrm{NO}_{3}^{-}\right.$; Epstein and Bloom, 2005). Therefore, this review focuses on this form.

Many studies have shown that elevated $\mathrm{CO}_{2}$ stimulates photosynthesis, plant growth, and demand for mineral nutrients. 
High variability in plant growth and photosynthetic responses to elevated $\mathrm{CO}_{2}$ may result from vast experimental differences in soil $\mathrm{NO}_{3}^{-}$concentration. In natural systems, soil $\mathrm{NO}_{3}^{-}$is typically around $1 \mathrm{mM}$ (Andrews, 1986b), but in fertilized agricultural soils, $\mathrm{NO}_{3}^{-}$can be much higher, ranging from 10 to $70 \mathrm{mM}$ (Reisenauer, 1966). The negative charge of $\mathrm{NO}_{3}^{-}$prevents it from binding to most soil particles, and this contributes to substantial spatial and temporal heterogeneity in soil $\mathrm{NO}_{3}^{-}$availability (Jackson and Caldwell, 1993). Plants have responded to soil $\mathrm{NO}_{3}^{-}$variability with adaptations to increase $\mathrm{NO}_{3}^{-}$uptake rapidly when it is available. In response to high soil $\mathrm{NO}_{3}^{-}$, individual roots increase $\mathrm{NO}_{3}^{-}$uptake (Forde, 2002a) and alter root hydraulic properties to increase mass flow (Gorska et al., 2008). These adaptations allow a few roots in a high $\mathrm{NO}_{3}^{-}$region of the soil to provide all the $\mathrm{N}$ that the shoot requires (Laine et al., 1995).

\section{ROOT TO SHOOT N SIGNALING}

Root to shoot communication of soil $\mathrm{N}$ availability may be as simple as $\mathrm{NO}_{3}^{-}$delivery from roots to shoots in xylem sap (Takei et al., 2002). When soil $\mathrm{NO}_{3}^{-}$is low, root $\mathrm{C} / \mathrm{N}$ ratios are high and roots have sufficient carbohydrate to assimilate most of the $\mathrm{NO}_{3}^{-}$that they absorb (Andrews et al., 1992) and thus deliver little $\mathrm{NO}_{3}^{-}$to shoots. As soil $\mathrm{NO}_{3}^{-}$increases, a greater proportion of absorbed $\mathrm{NO}_{3}^{-}$remains unassimilated in the root and is transported to the shoot (Andrews, 1986a; Agrell et al., 1994). Xylem sap $\mathrm{NO}_{3}^{-}$ directly links soil $\mathrm{N}$ availability to the shoot and thereby serves as an ideal signal for such a temporally and spatially variable nutrient. High shoot $\mathrm{NO}_{3}^{-}$stimulates shoot growth and low shoot $\mathrm{NO}_{3}^{-}$ inhibits shoot growth even when total shoot $\mathrm{N}$ is high (Walch-Liu et al., 2000; Rahayu et al., 2005). Species that predominantly transport $\mathrm{N}$ from root to shoot as amino acids instead of $\mathrm{NO}_{3}^{-}$may not use xylem sap $\mathrm{NO}_{3}^{-}$for root to shoot $\mathrm{N}$ signaling (Sprent and Thomas, 1984). Indeed, leaf growth is not always proportional to leaf $\mathrm{NO}_{3}^{-}$concentration (Rahayu et al., 2005), indicating the importance of other signals such as phytohormones for root to shoot communication of root $\mathrm{N}$ supply.

One class of phytohormones involved in root to shoot signaling is cytokinins. Stimulation of leaf growth by $\mathrm{N}$ supply is associated with increased concentrations of active forms of cytokinins (Rahayu et al., 2005). Root cytokinin production and xylem sap delivery of cytokinins to shoots increase with $\mathrm{NO}_{3}^{-}$fertilization (Takei et al., 2001; Forde, 2002b). Cytokinins stimulate leaf growth, increase shoot sink strength (Werner et al., 2008), and delay leaf senescence (Gan and Amasino, 1995), while they inhibit root elongation. Xylem sap transport of cytokinins increases expression of $\mathrm{N}$ responsive genes in leaves (Sakakibara et al., 1999; Takei et al., 2001; Kiba et al., 2011; Ruffel et al., 2011). All of these responses to cytokinins suggest that these phytohormones serve as root to shoot signals for root $\mathrm{N}$ availability

\section{ELEVATED $\mathrm{CO}_{2}$ EFFECTS ON ROOT TO SHOOT N SIGNALS}

$\mathrm{CO}_{2}$ enrichment influences root to shoot $\mathrm{N}$ signaling through its effects on xylem sap flow rate, $\mathrm{NO}_{3}^{-}$assimilation, and root allocation.

Root to shoot signals of $\mathrm{N}$ availability depend upon xylem sap flow for rapid signal delivery, and elevated $\mathrm{CO}_{2}$ affects xylem flow rates. Elevated $\mathrm{CO}_{2}$ decreases transpiration rates between
5 and $20 \%$ as stomata close in response to higher intercellular $\mathrm{CO}_{2}$ concentration (Leakey et al., 2009). Stomatal closure slows water uptake and thereby xylem sap flow rate. Decreased transpiration may impede mass flow of $\mathrm{NO}_{3}^{-}$in the soil solution to roots (McDonald et al., 2002), but this decrease may not slow delivery of $\mathrm{N}$ to shoots (Schulze and Bloom, 1984) because $\mathrm{N}$ concentration in the xylem sap increases as xylem sap flow decreases, maintaining $\mathrm{N}$ delivery rates (Shaner and Boyer, 1975; Schulze and Bloom, 1984). Increasing xylem loading of $\mathrm{N}$ in roots does not require substantial energy in that xylem solute $\mathrm{N}$ concentrations are relatively low. Xylem concentrations of cytokinins are in the nanomolar range (Foo et al., 2007), and so are even less likely to be affected by xylem sap flow rates.

Elevated $\mathrm{CO}_{2}$ may disrupt root to shoot $\mathrm{N}$ signaling through shifting the location of $\mathrm{NO}_{3}^{-}$assimilation. Greater rates of photosynthesis at elevated $\mathrm{CO}_{2}$ increase carbohydrate flux to roots (Grimmer and Komor, 1999). In the root, higher carbohydrates increase $\mathrm{NO}_{3}^{-}$assimilation (Matt et al., 2001), growth, and local demand for $\mathrm{N}$ (Kircher and Schopfer, 2012). Consequently, the root transports less $\mathrm{NO}_{3}^{-}$to the shoot, and xylem sap $\mathrm{NO}_{3}^{-}$ becomes less effective as a signal of root $\mathrm{N}$ availability.

Plant allocation of carbohydrate to roots varies greatly with $\mathrm{CO}_{2}$ enrichment (Rogers et al., 1996). For species in which carbohydrate flux to roots is insensitive to $\mathrm{CO}_{2}$, the relationship among root $\mathrm{NO}_{3}^{-}$assimilation, root $\mathrm{N}$ utilization, and xylem sap $\mathrm{NO}_{3}^{-}$ transport could indicate the potential for improving root to shoot $\mathrm{N}$ signaling at elevated $\mathrm{CO}_{2}$. For species in which $\mathrm{CO}_{2}$ enrichment increases carbohydrate flux, elevated $\mathrm{CO}_{2}$ may disrupt cytokinin signaling. A low baseline level of root cytokinin production at low root available $\mathrm{NO}_{3}^{-}$(Samuelson and Larsson, 1993) may result in greater root xylem cytokinin loading when root allocation is high under long-term growth at elevated $\mathrm{CO}_{2}$ (Yong et al., 2000). High rates of cytokinin delivery to shoots could induce shoot growth in excess of what can be supported by root $\mathrm{N}$ supply. This could partially explain the decline in leaf $\mathrm{N}$ after prolonged exposure to elevated $\mathrm{CO}_{2}$ (Oren et al., 2001). Additional study of xylem sap and leaf cytokinins at elevated $\mathrm{CO}_{2}$ are necessary to determine if this disruption in cytokinin signaling is responsible for declining leaf $\mathrm{N}$ content.

\section{SHOOT TO ROOT N SIGNALING}

When soil $\mathrm{NO}_{3}^{-}$is high, a few roots $-3.5 \%$ of the root system in spring wheat (Robinson et al., 1991) and 12\% in lettuce (Burns, 1991) - can supply leaves with all of their N. When leaf $\mathrm{N}$ becomes limiting, plants may enhance root uptake by increasing (1) root growth, (2) root transporters to absorb soil N, and (3) root exudation to stimulate soil microbe activity that accelerates mineralization (Hawkes et al., 2005). All of these $\mathrm{N}$ acquisition strategies expend carbohydrate exported from shoots, and coordination of these processes is essential for optimal plant growth. Signals that stimulate root growth when leaf $\mathrm{N}$ is low or that repress root growth when leaf $\mathrm{N}$ is high balance root $\mathrm{N}$ acquisition and shoot demand.

A significant portion of $\mathrm{N}$ transported to shoots is recycled to roots via phloem transport of amino acids (Forde and Clarkson, 1999). It has been hypothesized that this transport of amino acids from shoots to roots in phloem could allow for feedback inhibition 
of root growth and $\mathrm{NO}_{3}^{-}$assimilation (Marschner, 1986; Imsande and Touraine, 1994; Marschner etal., 1996). Although exogenously supplied amino acids can inhibit root growth and $\mathrm{NO}_{3}^{-}$ uptake (Orsel et al., 2002; Forde and Walch-Liu, 2009), composition and transport of amino acids in phloem often do not correlate with shoot $\mathrm{N}$ status or root $\mathrm{NO}_{3}^{-}$uptake (Forde, 2002a). In split root experiments, amino acids were preferentially transported to portions of root systems supplied with $\mathrm{NO}_{3}^{-}$rather than those deprived of exogenous $\mathrm{N}$, and the roots receiving more amino acids had higher growth rates (Tillard et al., 1998). This supports that amino acids delivered via the phloem stimulate root growth rather than inhibit it (Marschner et al., 1996).

Auxins are primarily synthesized in shoots and inhibit shoot branching (Normanly et al., 1995; Ljung et al., 2001). They are transported to roots through polar transport in the phloem (Baker, 2000) and promote proliferation of lateral roots. Phloem and root auxin concentrations decrease when plants are grown at high $\mathrm{NO}_{3}^{-}$ (Caba et al., 2000; Tian et al., 2008) and increase in roots when $\mathrm{N}$ is limiting (Walch-Liu et al., 2006). Therefore, auxins are prime candidates for signals that communicate shoot $\mathrm{NO}_{3}^{-}$levels to roots (Forde, 2002b). Roots rely on photosynthesizing organs for carbohydrates, and thus, auxin-induced increases in root growth depend upon root carbohydrate supply (Reed et al., 1998; Bhalerao et al., 2002; Zhang et al., 2007).

The amount of carbohydrate transported in phloem sap from shoots to roots may also signal shoot $\mathrm{N}$ status, and this carbohydrate signaling mechanism appears to be independent of phloem transport of auxin (Bingham et al., 1998). At high leaf N, shoot growth acts as a sink for shoot produced carbohydrates and relatively little carbohydrate is transported to roots. If leaf $\mathrm{N}$ is low, shoot growth is limited and more carbohydrate is transported to roots (Brouwer, 1967; Brouwer and DeWit, 1969; Bloom et al., 1993; Kallarackal et al., 2012). High root carbohydrates increases root elongation and lateral root initiation (Bingham et al., 1998; Kircher and Schopfer, 2012), increases root area for $\mathrm{N}$ acquisition, and upregulates $\mathrm{NO}_{3}^{-}$uptake and assimilation (Lejay et al., 1999; Ono et al., 2000; Matt et al., 2001).

\section{ELEVATED $\mathrm{CO}_{2}$ EFFECTS ON SHOOT TO ROOT N SIGNALING}

Leaf $\mathrm{N}$ concentrations decline under prolonged growth at elevated $\mathrm{CO}_{2}$ (Oren et al., 2001). Photosynthetic acclimation can account for some of this decrease (Long et al., 2004), but fertilization with $\mathrm{NH}_{4} \mathrm{NO}_{3}$ eliminates it (Crous et al., 2010; Liu et al., 2011), showing that increased N supply can compensate for the effects of elevated $\mathrm{CO}_{2}$ through enhanced root $\mathrm{N}$ uptake and plant $\mathrm{N}$ assimilation. This suggests that elevated $\mathrm{CO}_{2}$ interrupts shoot to root $\mathrm{N}$ signaling.

Amino acids in the phloem, potential signals of shoot $\mathrm{N}$ status, do not show a consistent response to elevated $\mathrm{CO}_{2}$ (Docherty et al., 1997; Sicher, 2008). By contrast, leaf and root auxins increase under elevated $\mathrm{CO}_{2}$ and stimulate root growth (Teng et al., 2006; Wang et al., 2009; Niu etal., 2011). Other processes, however, such as carbohydrate transport or shoot $\mathrm{NO}_{3}^{-}$assimilation, may limit the ability of increased root auxins to stimulate root $\mathrm{N}$ uptake.

Carbohydrate transport through the phloem is driven by a carbohydrate concentration gradient (van Bel, 2003). Higher rates of net photosynthesis under elevated $\mathrm{CO}_{2}$ increase carbohydrate delivery to roots and can increase root respiration and root $\mathrm{NO}_{3}^{-}$ assimilation (Bassirirad et al., 1996; Fonseca et al., 1997; Kruse et al., 2002). High carbohydrate delivery to roots of $\mathrm{C}_{3}$ plants under long-term growth at elevated $\mathrm{CO}_{2}$ can also increase root growth (Berntson and Bazzaz, 1996; Kimball et al., 2002) and root carbohydrate exudation (Berntson et al., 1997). Carbohydrate flow from shoots to roots, however, does not increase proportionally to photosynthesis at elevated $\mathrm{CO}_{2}$. For example, elevated $\mathrm{CO}_{2}$ increases photosynthesis in $\mathrm{C}_{3}$ species, but carbohydrate export from the leaves may not increase proportional to this carbon fixation (Grodzinski et al., 1998). This probably derives from leaf carbohydrate production under elevated $\mathrm{CO}_{2}$ exceeding phloem export capacity (Korner et al., 1995; Komor, 2000).

In most tropical and subtropical plants and in temperate plants at high soil $\mathrm{NO}_{3}^{-}$, most $\mathrm{NO}_{3}^{-}$assimilation occurs in shoots because $\mathrm{NO}_{3}^{-}$photoassimilation in shoots is more energy efficient than respiratory-driven $\mathrm{NO}_{3}^{-}$and $\mathrm{NO}_{2}^{-}$reduction in roots (Andrews, 1986b). Elevated $\mathrm{CO}_{2}$ inhibits shoot $\mathrm{NO}_{3}^{-}$assimilation in $\mathrm{C}_{3}$ plants (Rachmilevitch et al., 2004; Bloom et al., 2010), necessitating a greater reliance on root $\mathrm{NO}_{3}^{-}$assimilation to maintain plant capacity for $\mathrm{NO}_{3}^{-}$assimilation. In tobacco, 3 weeks of $\mathrm{CO}_{2}$ enrichment enhances root $\mathrm{NO}_{3}^{-}$assimilation and may compensate for decreasing shoot $\mathrm{NO}_{3}^{-}$assimilation when there is sufficient root carbohydrate (Kruse et al., 2002). A shift from shoot $\mathrm{NO}_{3}^{-}$assimilation to root $\mathrm{NO}_{3}^{-}$assimilation requires translocation of more carbohydrate to the roots to provide sufficient energy and carbon skeletons for these processes (Zheng, 2009). $\mathrm{NH}_{4}^{+}$ fertilization decreases the limitations of phloem carbohydrate transport on plant $\mathrm{N}$ status because $\mathrm{NH}_{4}^{+}$assimilation requires less carbohydrate.

\section{WATER STRESS SIGNALING}

Photosynthesis in land plants results in the inevitable water loss during $\mathrm{CO}_{2}$ uptake because both diffusion of $\mathrm{CO}_{2}$ into leaves and water vapor out of leaves occur through stomata. Soil drought, salinity, and chilling can result in an inability of water transport from roots to match shoot water loss. To maintain leaf photosynthesis, shoot turgor, and shoot growth, plants under water stress rely on local root responses that increase water uptake as well as shoot responses that reduce water use.

During drought or salt stress, xylem tension acts as an integrative hydraulic signal of soil water potential that rapidly communicates soil water stress to leaves (Malone, 1993). Likewise, low root hydraulic conductance during root chilling results in rapidly increasing xylem tension and declining leaf turgor (Bloom et al., 2004). Turgor loss causes stomatal closure through either passive or active regulation (Tardieu and Davies, 1993) and inhibits leaf growth as leaf cell turgor declines below the threshold for cell wall expansion (Hsiao and Acevedo, 1974). Smaller leaf area and stomatal closure resulting from decreased leaf turgor protect leaves from desiccation. During slowly developing soil drought, soil moisture content has substantial heterogeneity, but hydraulic signals are integrative; that is, xylem tension in leaves is affected by xylem tension in all connected roots. Roots in drier regions experience greater decreases in water potential before hydraulic signals are transmitted to leaves. Non-hydraulic 
signals can be generated in these roots with lower water potential, allowing shoots to preemptively reduce shoot water use before leaf water deficit develops (Dodd et al., 2008). During root chilling, chilling tolerant species close stomata before declines in leaf water potential occur, indicating that non-hydraulic chemical signals are also important in response to this type of water stress (Bloom et al., 2004).

Abscisic acid (ABA) increases with drought and salinity, induces stomatal closure, and inhibits transpirational water loss (Davies and Zhang, 1991; Bahrun et al., 2002; Jia et al., 2002). Low root water potential increases both root ABA production (Simonneau et al., 1998) and xylem sap transport of ABA from root to shoot (Zhang and Davies, 1989). ABA production also increases during chilling stress in the long-term (Melkonian et al., 2004), but the rapidity of stomatal closure during root chilling indicates that other, more rapidly produced root to shoot signals are involved in root chilling.

Abscisic acid-induced stomatal closure is not solely dependent on root ABA production. Shoot vascular tissue ABA production (Endo et al., 2008) and ABA uptake by leaf symplast also affect guard cell ABA concentration. Xylem sap $\mathrm{pH}$ increases with soil drought, salinity, and root chilling, slows leaf symplastic ABA uptake, and increases guard cell ABA concentration, thereby promoting stomatal closure (Vernieri etal., 2001; Wilkinson and Davies, 2002; Felle et al., 2005; Wilkinson et al., 2007).

Evidence is mounting for non-hydraulic signals other than $\mathrm{ABA}$ and $\mathrm{pH}$ in xylem sap that also affect stomatal regulation during water stress (Munns, 1992; Chen et al., 2002; Holbrook et al., 2002). For example, salts carried in the transpiration stream can also act as long distance root to shoot signals. During salinity stress $\mathrm{Na}^{+}$and $\mathrm{Cl}^{-}$are transported in xylem sap and concentrated at sites of evaporation in leaves. High leaf apoplastic $\mathrm{Na}^{+}$and $\mathrm{Cl}^{-}$decrease water potential, prompting osmotic adjustment and, in some halophytes, stomatal closure (Very et al., 1998).

Shoot to root signaling is also important for responses to chilling and high vapor pressure deficit stresses that do not directly affect root water potential. During both of these stresses, transpiration exceeds the capacity for root water transport. High root $\mathrm{ABA}$ increases root hydraulic conductance and water flow during chilling or at high vapor pressure deficit to ameliorate shoot water deficit (Markhart, 1984; Kudoyarova et al., 2011). This increase in root $\mathrm{ABA}$ requires water stress signaling from shoots; for example, if leaf water potential is maintained during chilling, there is no increase in root ABA (Vernieri et al., 2001). Shoot to root communication of shoot water deficits may be communicated hydraulically or through phloem transport of ABA or other signals.

\section{ELEVATED $\mathrm{CO}_{2}$ EFFECTS ON WATER STRESS SIGNALING}

The primary effect of elevated $\mathrm{CO}_{2}$ on water stress signaling derives from stomatal closure in response to high intercellular $\mathrm{CO}_{2}$ and the resulting lower transpiration rates (Leakey et al., 2009). Lower transpiration rates under elevated $\mathrm{CO}_{2}$ may decrease both accumulation of ABA at sites of evaporation near guard cells (Zhang and Outlaw, 2001) and foliar ABA concentration in general (Teng et al., 2006). Moreover, stomatal closure in response to root
ABA application and osmotic stress are greater at elevated $\mathrm{CO}_{2}$ (Leymarie et al., 1999) and may result from higher intercellular $\mathrm{CO}_{2}$. At ambient $\mathrm{CO}_{2}$, when stomata begin to close during water stress, low intercellular $\mathrm{CO}_{2}$ can partially reverse stomatal closure. At elevated $\mathrm{CO}_{2}$, intercellular $\mathrm{CO}_{2}$ remains high even after stomatal closure, and this can prevent reversal of stomatal closure.

Hydraulic signaling is also affected by lower transpiration rates at elevated $\mathrm{CO}_{2}$. Slower transpiration reduces leaf xylem tension and improves leaf water potential during drought (Xiao et al., 2005). This may mitigate midday declines in leaf water potential during early stages of drought that are necessary for shoot perception of water stress. Slower transpiration at elevated $\mathrm{CO}_{2}$ delays hydraulic signaling of declining root water potential, but does not delay non-hydraulic signaling. Non-hydraulic signals like ABA are still delivered to shoots at elevated $\mathrm{CO}_{2}$, decreasing shoot water use and further delaying hydraulic signaling of declining root water potential. Slower transpiration also minimizes development of leaf water deficit during chilling at elevated $\mathrm{CO}_{2}$ (Boese et al., 1997), which may inhibit root ABA production (Vernieri et al., 2001) that is important for root acclimation to chilling.

\section{CONCLUSION}

Leaf $\mathrm{N}$ concentration declines under prolonged growth at elevated $\mathrm{CO}_{2}$ (Oren et al., 2001) unless plants are heavily fertilized with $\mathrm{NH}_{4} \mathrm{NO}_{3}$ (Crous et al., 2010; Liu et al., 2011). This suggests that mechanisms for long distance root-shoot communication of root $\mathrm{N}$ availability and shoot $\mathrm{N}$ status, which evolved under low $\mathrm{CO}_{2}$, may lack plasticity to maintain root-shoot coordination under elevated $\mathrm{CO}_{2}$. Leaf and root auxin concentrations increase in response to low leaf $\mathrm{N}$ under elevated $\mathrm{CO}_{2}$ which should increase root growth, root $\mathrm{NO}_{3}^{-}$uptake, and root $\mathrm{NO}_{3}^{-}$ assimilation (Teng et al., 2006; Wang et al., 2009; Niu et al., 2011). However, root organic $\mathrm{N}$ supply to shoots may be limited by phloem carbohydrate transport from shoots to roots (Grodzinski et al., 1998); although these effects may not affect growth until stored leaf $\mathrm{N}$ is depleted. The accumulation of non-structural carbohydrates in leaves at elevated $\mathrm{CO}_{2}$ that is often observed (Long etal., 2004) may result from an inability to transport carbohydrate out of leaves or to obtain enough $\mathrm{N}$ from roots for shoot growth. Photosynthetic acclimation, whereby carbon fixation per unit leaf area declines under prolonged exposure to elevated $\mathrm{CO}_{2}$, decreases leaf $\mathrm{N}$ requirements and increases leaf phloem export capacity. This may mitigate phloem carbohydrate export limitations and thus improve shoot-root $\mathrm{N}$ signaling.

The improvement in leaf water potential and water use efficiency resulting from higher intercellular $\mathrm{CO}_{2}$ concentration are predicted to benefit plant growth under elevated $\mathrm{CO}_{2}$, but productivity gains at elevated $\mathrm{CO}_{2}$ under water limitation are often lower than predicted (Nowak et al., 2004; Newingham et al., 2013). Slower transpiration impedes development of leaf water deficits important for shoot water stress perception as soil water potential declines. Plants generate ABA and other non-hydraulic signals of low root water potential, and these can decrease stomatal conductance and shoot growth before declines in leaf water 
Table 1 | Root-shoot $\mathrm{N}$ and water signal responses to elevated $\mathrm{CO}_{2}$.

\begin{tabular}{|c|c|c|}
\hline Signal & Role & Response to elevated $\mathrm{CO}_{2}$ \\
\hline $\mathrm{NO}_{3}^{-}$ & Root to shoot signal of root $\mathrm{NO}_{3}^{-}$availability & $\begin{array}{l}\text { Root } \mathrm{NO}_{3}^{-} \text {assimilation, local root demand for } \mathrm{N} \text { increase, and xylem transport of } \\
\mathrm{NO}_{3}^{-} \text {decreases }\end{array}$ \\
\hline Cytokinin & Root to shoot signal of root $\mathrm{NO}_{3}^{-}$availability & Cytokinin production and xylem transport increases even at low root available $\mathrm{NO}_{3}^{-}$ \\
\hline Auxin & Shoot to root signal of leaf $\mathrm{N}$ availability & Auxin production and transport to roots increases in response to low leaf $\mathrm{N}$ \\
\hline Carbohydrate & Shoot to root signal of leaf $\mathrm{N}$ availability & $\begin{array}{l}\text { Increased carbohydrate delivery to roots, but delivery does not increase proportion- } \\
\text { ally with leaf carbohydrate production }\end{array}$ \\
\hline Xylem tension & Bidirectional signal of root or shoot water stress & $\begin{array}{l}\text { Stomatal closure reduces leaf xylem tension delaying shoot perception of water } \\
\text { stress }\end{array}$ \\
\hline ABA & Bidirectional signal of root or shoot water stress & $\begin{array}{l}\text { Transpirational accumulation of leaf and guard cell ABA decreases and stomatal } \\
\text { sensitivity to ABA increases }\end{array}$ \\
\hline
\end{tabular}

potential occur. While stomatal closure from these non-hydraulic water stress signals has less negative impact on photosynthesis at elevated $\mathrm{CO}_{2}$ as compared to ambient $\mathrm{CO}_{2}$, these signals can still unnecessarily limit shoot growth (Leymarie et al., 1999). Greater stomatal sensitivity to osmotic and drought stress results in high water use efficiency and less negative leaf water potential, but more conservative shoot growth and lower potential productivity (Warren et al., 2011).

Shoot-root $\mathrm{N}$ and water signaling involve both resource and phytohormone transport from source organs to distant sink

\section{REFERENCES}

Agrell, D., Oscarson, P., and Larsson, C. M. (1994). Translocation of $\mathrm{N}$ to and from barley roots - its dependence on local nitrate supply in split-root culture. Physiol. Plant. 90, 467474. doi: 10.1111/j.1399-3054.1994. tb08803.x

Andrews, M. (1986a). Nitrate and reduced-N concentrations in the xylem sap of Stellaria media, Xanthium strumarium and 6 legume species. Plant Cell Environ. 9, 605-608. doi: 10.1111/13653040.ep11616359

Andrews, M. (1986b). The partitioning of nitrate assimilation between root and shoot of higher plants. Plant Cell Environ. 9, 511-519. doi: 10.1111/1365-3040.ep11616228

Andrews, M., Morton, J. D., Lieffering, M., and Bisset, L. (1992). The partitioning of nitrate assimilation between root and shoot of a range of temperate cereals and pasture grasses. Ann. Bot. 70, 271-276.

Bahrun, A., Jensen, C. R., Asch, F., and Mogensen, V. O. (2002). Droughtinduced changes in xylem $\mathrm{pH}$, ionic composition, and ABA concentration act as early signals in field-grown maize (Zea mays L.). J. Exp. Bot. 53, 251-263. doi: 10.1093/jexbot/53. 367.251
Baker, D. (2000). Vascular transport of auxins and cytokinins in Ricinus. Plant Growth Regul. 32, 157-160. doi: 10.1023/A:1010749411009

Bassirirad, H., Thomas, R. B., Reynolds J. F., and Strain, B. R. (1996). Differential responses of root uptake kinetics of $\mathrm{NH} 4+$ and NO3- to enriched atmospheric $\mathrm{CO} 2$ concentration in field-grown loblolly pine. Plant Cell Environ. 19, 367371. doi: 10.1111/j.1365-3040.1996. tb00260.x

Beerling, D. J., and Chaloner, W. G. (1993). Evolutionary responses of stomatal density to global $\mathrm{CO} 2$ change. Biol. J. Linn. Soc. 48, 343353. doi: 10.1016/0024-4066(93) 90005-9

Berntson, G. M., and Bazzaz, F. A. (1996). The allometry of root production and loss in seedlings of Acer rubrum (Aceraceae) and Betula papyrifera (Betulaceae): implications for root dynamics in elevated $\mathrm{CO} 2$. Am. J. Bot. 83, 608-616. doi: 10.2307/ 2445920

Berntson, G. M., Wayne, P. M., and Bazzaz, F. A. (1997). Belowground architectural and mycorrhizal responses to elevated $\mathrm{CO} 2$ in Betula alleghaniensis populations. Funct. Ecol. 11, 684-695. doi: 10.1046/j.1365-2435.1997.00141.X

organs to achieve a functional equilibrium between roots and shoots. Rising atmospheric $\mathrm{CO}_{2}$ concentrations will increase net photosynthesis, decrease water use, and may alter source-sink interactions beyond the capability of signaling mechanisms that evolved at the lower atmospheric $\mathrm{CO}_{2}$ concentrations, which have prevailed throughout recent history (Table 1). Critical assessment of limitations in shoot-root signaling at elevated $\mathrm{CO}_{2}$ and careful genetic manipulations of $\mathrm{N}$ and water signaling could enhance crop response to rising atmospheric $\mathrm{CO}_{2}$ and avoid declines in plant N.

Bhalerao, R. P., Eklof, J., Ljung, K. Marchant, A., Bennett, M., and Sandberg, G. (2002). Shoot-derived auxin is essential for early lateral root emergence in Arabidopsis seedlings. Plant J. 29, 325-332. doi: 10.1046/j.09607412.2001.01217.

Bingham, I. J., Blackwood, J. M., and Stevenson, E. A. (1998). Relationship between tissue sugar content, phloem import and lateral root initiation in wheat. Physiol. Plant. 103, 107113. doi: 10.1034/j.1399-3054.1998. 1030113.x

Bloom, A. J. (1997). "Nitrogen as a limiting factor: crop acquisition of ammonium and nitrate," in Ecol ogy in Agriculture, ed. L. E. Jackson (San Diego: Academic Press), 145 172. doi: 10.1016/B978-0123782601/50006-3

Bloom, A. J., Burger, M., Asensio, J. S. R., and Cousins, A B. (2010). Carbon dioxide enrichment inhibits nitrate assimilation in wheat and Arabidopsis. Science 328, 899-903. doi: 10.1126/science. 1186440

Bloom, A. J., Chapin, F. S. III, and Mooney, H. A. (1985). Resource limitation in plants: an economic analogy. Annu. Rev. Ecol. Syst. 16, 363-392. doi: 10.1146/annurev. ecolsys.16.1.363
Bloom, A. J., Jackson, L. E., and Smart, D. R. (1993). Root growth as a function of ammonium and nitrate in the root zone. Plant Cell Environ. 16, 199-206. doi: 10.1111/j.13653040.1993.tb00861.x

Bloom, A. J., Zwieniecki, M. A., Passioura, J. B., Randall, L. B., Holbrook, N. M., and St. Clair, D. A. (2004). Water relations under root chilling in a sensitive and tolerant tomato species. Plant Cell Environ. 27, 971979. doi: 10.1111/j.1365-3040.2004. 01200.x

Boese, S. R., Wolfe, D. W., and Melkonian, J. J. (1997). Elevated $\mathrm{CO} 2$ mitigates chilling-induced water stress and photosynthetic reduction during chilling. Plant Cell Environ. 20, 625-632. doi: 10.1111/j.13653040.1997.00082.x

Boyce, C. K., and Zwieniecki, M. A. (2012). Leaf fossil record suggests limited influence of atmospheric $\mathrm{CO} 2$ on terrestrial productivity prior to angiosperm evolution. Proc. Natl. Acad. Sci. U.S.A. 109, 10403-10408. doi: 10.1073/pnas. 1203769109

Boyer, J. S. (1982). Plant productivity and environment. Science 218, 443-448. doi: 10.1126/science.218. 4571.443

Brouwer, R. (1967). Beziehungen zwischen Spross- und Wurzelwachstum 
[Relationships between shoot and root growth]. Angew. Bot. 41, 244 250

Brouwer, R., and DeWit, C. T. (1969). "A simulation model of plant growth with special attention to root growth and its consequences," in Root Growth, ed. W. J. Whittington (London: Butterworths), 224-244.

Burns, I. G. (1991). Short- and longterm effects of a change in the spatial distribution of nitrate in the root zone on $\mathrm{N}$ uptake, growth and root development of young lettuce plants. Plant Cell Environ. 14, 21-33. doi: 10.1111/j.1365-3040.1991.tb01368.x

Caba, J. M., Centeno, M. L., Fernandez, B., Gresshoff, P. M., and Ligero, F. (2000). Inoculation and nitrate alter phytohormone levels in soybean roots: differences between a supernodulating mutant and the wild type. Planta 211, 98-104. doi: 10.1007/ s004250000265

Chen, G. X., Lips, S. H., and Sagi, M. (2002). Biomass production, transpiration rate and endogenous abscisic acid levels in grafts of flacca and wild-type tomato (Lycopersicon esculentum). Funct. Plant Biol. 29, 1329 1335. doi: 10.1071/PP01263

Crous, K. Y., Reich, P. B., Hunter, M. D., and Ellsworth, D. S. (2010). Maintenance of leaf $\mathrm{N}$ controls the photosynthetic $\mathrm{CO} 2$ response of grassland species exposed to 9 years of free-air CO2 enrichment. Glob. Chang. Biol. 16, 2076-2088. doi: 10.1111/j.13652486.2009.02058.x

Davies, W. J., and Zhang, J. H. (1991). Root signal and the regulation of growth and development of plants in drying soil. Annu. Rev. Plant Phys. 42, 55-76. doi: 10.1146/annurev.pp.42. 060191.000415

Docherty, M., Wade, F. A., Hurst, D. K., Whittaker, J. B., and Lea, P. J. (1997). Responses of tree sap-feeding herbivores to elevated CO2. Glob. Chang. Biol. 3, 51-59. doi: 10.1046/j.13652486.1997.00096.x

Dodd, I. C., Egea, G., and Davies, W. J. (2008). Accounting for sap flow from different parts of the root system improves the prediction of xylem ABA concentration in plants grown with heterogeneous soil moisture. J. Exp. Bot. 59, 4083-4093. doi: 10.1093/jxb/ern246

Dukes, J. S., Chiariello, N. R., Cleland, E. E., Moore, L. A., Shaw, M. R., Thayer, S., et al. (2005). Responses of grassland production to single and multiple global environmental changes. PLoS Biol. 3:e319. doi: 10.1371/journal.pbio.0030319

Ehleringer, J. R., Sage, R. F., Flanagan, L. B., and Pearcy, R. W. (1991).
Climate change and the evolution of C4 photosynthesis. Trends Ecol. Evo. 6, 95-99. doi: 10.1016/01695347(91)90183-X

Endo, A., Sawada, Y., Takahashi, H. Okamoto, M., Ikegami, K., Koiwai, H., et al. (2008). Drought induction of Arabidopsis 9-cis-epoxycarotenoid dioxygenase occurs in vascular parenchyma cells. Plant Physiol. 147, 1984-1993. doi: 10.1104/pp. 108.116632

Epstein, E., and Bloom, A. J. (2005). Mineral Nutrition of Plants: Principles and Perspectives. Sunderland: Sinauer Associates.

Felle, H. H., Herrmann, A., Huckelhoven, R., and Kogel, K. H. (2005). Root-to-shoot signalling: apoplastic alkalinization, a general stress response and defence factor in barley (Hordeum vulgare). Protoplasma 227, 17-24.doi: 10.1007/s00709-0050131-5

Field, C. B., and Mooney, H. A. (1986). "The photosynthesis-nitrogen relationship in wild plants," in On the Economy of Plant Form and Function, ed. T. J. Givnish (Cambridge: Cambridge University Press), 25-56.

Fonseca, F., Bowsher, C. G., and Stulen, I. (1997). Impact of elevated atmospheric $\mathrm{CO} 2$ on nitrate reductase transcription and activity in leaves and roots of Plantago major. Physiol. Plant. 100, 940948. doi: 10.1034/j.1399-3054.1997. 1000421. $\mathrm{x}$

Foo, E., Morris, S. E., Parmenter, K. Young, N., Wang, H. T., Jones, A., et al. (2007). Feedback regulation of xylem cytokinin content is conserved in pea and Arabidopsis. Plant Physiol. 143, 1418-1428. doi: 10.1104/pp.106. 093708

Forde, B. G. (2002a). Local and long-range signaling pathways regulating plant responses to nitrate. Annu. Rev. Plant Phys. 53, 203224. doi: 10.1146/annurev.arplant. 53.100301 .135256

Forde, B. G. (2002b). The role of longdistance signalling in plant responses to nitrate and other nutrients. J. Exp. Bot. 53, 39-43. doi: 10.1093/jexbot/ 53.366.39

Forde, B. G., and Clarkson, D. T. (1999). Nitrate and ammonium nutrition of plants: physiological and molecular perspective. Adv. Bot. Res. 30, 1-90. doi: 10.1016/S0065-2296(08) 60226-8

Forde, B. G., and Walch-Liu, P. (2009). Nitrate and glutamate as environmental cues for behavioural responses in plant roots. Plant Cell Environ. 32, 682-693. doi: 10.1111/j.1365-3040.2008.01927.x
Gan, S., and Amasino, R. M. (1995). Inhibition of leaf senescence by autoregulated production of cytokinin. Science 270, 1986-1988. doi: 10.1126/science.270.5244.1986

Gorska, A., Ye, Q., Holbrook, N. M., and Zwieniecki, M. A. (2008). Nitrate control of root hydraulic properties in plants: translating local information to whole plant response. Plant Physiol. 148, 1159-1167. doi: 10.1104/pp.108.122499

Grimmer, C., and Komor, E. (1999). Assimilate export by leaves of Ricinus communis L. growing under normal and elevated carbon dioxide concentrations: the same rate during the day, a different rate at night. Planta 209, 275-281. doi: 10.1007/ s004250050633

Grodzinski, B., Jiao, J. R., and Leonardos, E. D. (1998). Estimating photosynthesis and concurrent export rates in C-3 and C-4 species at ambient and elevated CO2. Plant Physiol. 117, 207-215. doi: 10.1104/pp.117.1.207

Hawkes, C. V., Wren, I. F., Herman, D. J., and Firestone, M. K. (2005). Plant invasion alters nitrogen cycling by modifying the soil nitrifying community. Ecol. Lett. 8, 976-985. doi: 10.1111/j.1461-0248.2005.00802.x

Holbrook, N. M., Shashidhar, V. R., James, R. A., and Munns, R. (2002). Stomatal control in tomato with ABA-deficient roots: response of grafted plants to soil drying. J. Exp. Bot. 53, 1503-1514. doi: 10.1093/ jexbot/53.373.1503

Hsiao, T. C., and Acevedo, E. (1974). Plant responses to water deficits, water-use efficiency, and drought resistance. Agr. Meteorol. 14, 59-84. doi: 10.1016/0002-1571(74)90011-9

Imsande, J., and Touraine, B. (1994). N demand and the regulation of nitrate uptake. Plant Physiol. 105, 3-7.

Jackson, R. B., and Caldwell, M. M. (1993). The scale of nutrient heterogeneity around individual plants and its quantification with geostatistics. Ecology 74, 612-614. doi: 10.2307/ 1939320

Jia, W. S., Wang, Y. Q., Zhang, S. Q., and Zhang, J. H. (2002). Salt-stressinduced ABA accumulation is more sensitively triggered in roots than in shoots. J. Exp. Bot. 53, 2201-2206. doi: 10.1093/jxb/erf079

Joos, F., Plattner, G. K., Stocker, T. F., Marchal, O., and Schmittner, A. (1999). Global warming and marine carbon cycle feedbacks on future atmospheric CO2. Science 284 464-467. doi: 10.1126/science. 284 . 5413.464

Kallarackal, J., Bauer, S. N., Nowak, H., Hajirezaei, M. R., and Komor,
E. (2012). Diurnal changes in assimilate concentrations and fluxes in the phloem of castor bean (Ricinus communis L.) and tansy (Tanacetum vulgare L.). Planta 236, 209-223. doi: 10.1007/s00425-012-1600-7

Kiba, T., Kudo, T., Kojima, M., and Sakakibara, H. (2011). Hormonal control of nitrogen acquisition: roles of auxin, abscisic acid, and cytokinin. J. Exp. Bot. 62, 1399-1409. doi: 10.1093/jxb/erq410

Kimball, B. A., Idso, S. B., Johnson, S., and Rillig, M. C. (2007). Seventeen years of carbon dioxide enrichment of sour orange trees: final results. Glob. Chang. Biol. 13, 21712183. doi: 10.1111/j.1365-2486.2007. 01430.x

Kimball, B. A., Kobayashi, K., and Bindi, M. (2002). Responses of agricultural crops to free-air $\mathrm{CO} 2$ enrichment. Adv. Agron. 77, 293-368. doi: 10.1016/S0065-2113(02)77017-X

Kircher, S., and Schopfer, P. (2012). Photosynthetic sucrose acts as cotyledon-derived long-distance signal to control root growth during early seedling development in Arabidopsis. Proc. Natl. Acad. Sci. U.S.A. 109, 11217-11221. doi: 10.1073/ pnas. 1203746109

Komor, E. (2000). Source physiology and assimilate transport: the interaction of sucrose metabolism, starch storage and phloem export in source leaves and the effects on sugar status in phloem. Aust. J. Plant Physiol. 27, 497-505.doi: 10.1071/PP99127

Korner, C. (2006). Plant CO2 responses: an issue of definition, time and resource supply. New Phytol. 172, 393-411. doi: 10.1111/j.1469-8137. 2006.01886.x

Korner, C., Pelaezriedl, S., and Vanbel, A. J. E. (1995). CO2 responsiveness of plants - a possible link to phloem loading. Plant Cell Environ. 18, 595-600. doi: 10.1111/j.13653040.1995.tb00560.x

Kruse, J., Hetzger, I., Hansch, R., Mendel, R. R., Walch-Liu, P., Engels, C., etal. (2002). Elevated pCO2 favours nitrate reduction in the roots of wild-type tobacco (Nicotiana tabacum cv. Gat.) and significantly alters N-metabolism in transformants lacking functional nitrate reductase in the roots. J. Exp. Bot. 53, 2351-2367. doi: 10.1093/jxb/erf094

Kudoyarova, G., Veselova, S., Hartung, W., Farhutdinov, R., Veselov, D., and Sharipova, G. (2011). Involvement of root $\mathrm{ABA}$ and hydraulic conductivity in the control of water relations in wheat plants exposed to increased evaporative demand. Planta 233, 8794. doi: 10.1007/s00425-010-1286-7 
Laine, P., Ourry, A., and Boucaud, J. (1995). Shoot control of nitrate uptake rates by roots of Brassica napus L - effects of localized nitrate supply. Planta 196, 77-83. doi: 10.1007/ BF00193220

Leakey, A. D. B., Ainsworth, E. A., Bernacchi, C. J., Rogers, A., Long, S. P., and Ort, D. R. (2009). Elevated $\mathrm{CO} 2$ effects on plant carbon, nitrogen, and water relations: six important lessons from FACE. J. Exp. Bot. 60, 2859-2876. doi: 10.1093/jxb/ erp096

Lejay, L., Tillard, P., Lepetit, M., Olive, F. D., Filleur, S., Daniel-Vedele, F., etal. (1999). Molecular and functional regulation of two NO3- uptake systems by $\mathrm{N}$ - and C-status of Arabidopsis plants. Plant J. 18, 509519. doi: 10.1046/j.1365-313X.1999. 00480.x

Leymarie, J., Lasceve, G., and Vavasseur, A. (1999). Elevated CO2 enhances stomatal responses to osmotic stress and abscisic acid in Arabidopsis thaliana. Plant Cell Environ. 22, 301308. doi: 10.1046/j.1365-3040.1999. 00403.x

Liu, J. X., Zhou, G. Y., Xu, Z. H., Duan, H. L., Li, Y. L., and Zhang, D. Q. (2011). Photosynthesis acclimation, leaf nitrogen concentration, and growth of four tree species over 3 years in response to elevated carbon dioxide and nitrogen treatment in subtropical China. J. Soil. Sediment. 11, 1155-1164. doi: 10.1007/s11368011-0398-4

Ljung, K., Bhalerao, R. P., and Sandberg, G. (2001). Sites and homeostatic control of auxin biosynthesis in Arabidopsis during vegetative growth. Plant J. 28, 465-474. doi: 10.1046/j.1365-313X.2001.01173.x

Long, S. P., Ainsworth, E. A., Rogers, A., and Ort, D. R. (2004). Rising atmospheric carbon dioxide: plants face the future. Annu. Rev. Plant Biol. 55, 591-628. doi: 10.1146/annurev. arplant.55.031903.141610

Malone, M. (1993). Hydraulic signals. Philos. Trans. R. Soc. Lond. B 341 , 33-39. doi: 10.1098/rstb.1993.0088

Markhart, A. H. (1984). Amelioration of chilling-induced water-stress by abscisic acid-induced changes in root hydraulic conductance. Plant Physiol. 74, 81-83. doi: 10.1104/pp. 74.1.81

Marschner, H. (1986). Mineral Nutrition in Higher Plants. London: Academic Press, 674.

Marschner, H., Kirkby, E. A., and Cakmak, I. (1996). Effect of mineral nutritional status on shoot-root partitioning of photoassimilates and cycling. $J$.
Exp. Bot. 47, 1255-1263. doi: 10.1093/jxb/47.Special_Issue. 1255

Martin, T., Oswald, O., and Graham, I. A. (2002). Arabidopsis seedling growth, storage lipid mobilization, and photosynthetic gene expression are regulated by carbon:nitrogen availability. Plant Physiol. 128, 472481. doi: 10.1104/pp.010475

Matt, P., Geiger, M., Walch-Liu P., Engels, C., Krapp, A., and Stitt, M. (2001). The immediate cause of the diurnal changes of nitrogen metabolism in leaves of nitrate-replete tobacco: a major imbalance between the rate of nitrate reduction and the rates of nitrate uptake and ammonium metabolism during the first part of the light period. Plant Cell Environ. 24, 177-190. doi: 10.1111/j.13653040.2001.00676.x

McDonald, E. P., Erickson, J. E., and Kruger, E. L. (2002). Can decreased transpiration limit plant nitrogen acquisition in elevated $\mathrm{CO} 2$. Funct. Plant Biol. 29, 1115-1120. doi: 10.1071/FP02007

Melkonian, J., Yu, L. X., and Setter T. L. (2004). Chilling responses of maize (Zea mays L.) seedlings: root hydraulic conductance, abscisic acid and stomatal conductance. J. Exp. Bot. 55, 1751-1760. doi: 10.1093/jxb/ erh215

Munns, R. (1992). A leaf elongation assay detects an unknown growth inhibitor in xylem sap from wheat and barley. Aust. J. Plant Physiol. 19, 127-135. doi: 10.1071/PP9920127

Newingham, B. A., Vanier, C. H., Charlet, T. N., Ogle, K., Smith, S. D., and Nowak, R. S. (2013). No cumulative effect of 10 years of elevated [CO2] on perennial plant biomass components in the Mojave Desert. Glob. Chang. Biol. 19, 2168-2181. doi: $10.1111 /$ gcb.12177

Niu, Y. F., Jin, C. W., Jin, G. L., Zhou, Q. Y., Lin, X. Y., Tang, C. X., et al. (2011). Auxin modulates the enhanced development of root hairs in Arabidopsis thaliana (L.) Heynh. under elevated CO2. Plant Cell Environ. 34, 13041317. doi: 10.1111/j.1365-3040.2011. 02330.x

Normanly, J., Slovin, J. P., and Cohen, J. D. (1995). Rethinking auxin biosynthesis and metabolism. Plant Physiol. 107, 323-329.

Nowak, R. S., Ellsworth, D. S., and Smith, S. D. (2004). Functional responses of plants to elevated atmospheric CO2: do photosynthetic and productivity data from FACE experiments support early predictions? New Phytol. 162, 253-280. doi: 10.1111/j. 1469-8137.2004.01033.x
Ono, F., Frommer, W. B., and Von Wiren, N. (2000). Coordinated diurnal regulation of low- and high-affinity nitrate transporters in tomato. Plant Biol. 2, 17-23. doi: 10.1055/s-2000-297

Oren, R., Ellsworth, D. S., Johnsen, K. H., Phillips, N., Ewers, B. E. Maier, C., et al. (2001). Soil fertility limits carbon sequestration by forest ecosystems in a CO2-enriched atmosphere. Nature 411, 469-472. doi $10.1038 / 35078064$

Orsel, M., Filleur, S., Fraisier, V., and Daniel-Vedele, F. (2002). Nitrate transport in plants: which gene and which control? J. Exp. Bot. 53, 825833. doi: $10.1093 /$ jexbot $/ 53.370 .825$

Pearson, P. N., and Palmer, M. R. (2000). Atmospheric carbon dioxide concentrations over the past $60 \mathrm{mil}$ lion years. Nature 406, 695-699. doi: $10.1038 / 35021000$

Petit, J. R., Jouzel, J., Raynaud, D., Barkov, N. I., Barnola, J. M., Basile, I., et al. (1999). Climate and atmospheric history of the past 420,000 years from the Vostok ice core, Antarctica. Nature 399, 429-436. doi: $10.1038 / 20859$

Rachmilevitch, S., Cousins, A. B., and Bloom, A. J. (2004). Nitrate assimilation in plant shoots depends on photorespiration. Proc. Natl. Acad. Sci. U.S.A. 101, 11506-11510. doi 10.1073/pnas.0404388101

Rahayu, Y. S., Walch-Liu, P., Neumann, G., Romheld, V., Von Wiren, N., and Bangerth, F. (2005). Root-derived cytokinins as long-distance signals for NO3-induced stimulation of leaf growth. J. Exp. Bot. 56, 1143-1152. doi: $10.1093 / j x b / e r i 107$

Reed, R. C., Brady, S. R., and Muday, G. K. (1998). Inhibition of auxin movement from the shoot into the root inhibits lateral root development in Arabidopsis. Plant Physiol. 118, 13691378. doi: 10.1104/pp.118.4.1369

Reisenauer, H. M. (1966). "Mineral nutrients in soil solution," in Environmental Biology, eds P. L. Altman and D. S. Dittmer (Bethesda: Federation of American Societies for Experimental Biology), 507-508.

Robinson, D., Linehan, D. J., and Caul, S. (1991). What limits nitrate uptake from soil? Plant Cell Environ. $14,77-85$. doi: 10.1111/j.13653040.1991.tb01373.x

Rogers, H. H., Prior, S. A., Runion, G. B., and Mitchell, R. J. (1996). Root to shoot ratio of crops as influenced by CO2. Plant Soil 187, 229-248. doi: 10.1007/BF00017090

Ruffel, S., Krouk, G., Ristova, D., Shasha, D., Birnbaum, K. D., and Coruzzi, G. M. (2011). Nitrogen economics of root foraging: transitive closure of the nitrate-cytokinin relay and distinct systemic signaling for $\mathrm{N}$ supply vs. demand. Proc. Natl. Acad. Sci. U.S.A. 108, 18524-18529. doi: 10.1073/pnas.1108684108

Sakakibara, H., Hayakawa, A. Deji, A., Gawronski, S. W., and Sugiyama, T. (1999). His-Asp phosphotransfer possibly involved in the nitrogen signal transduction mediated by cytokinin in maize: molecular cloning of cDNAs for two-component regulatory factors and demonstration of phosphotransfer activity in vitro. Plant Mol. Biol. 41, 563-573. doi: 10.1023/A:1006391304881

Samuelson, M. E., and Larsson, C. M. (1993). Nitrate regulation of zeatin riboside levels in barley roots - effects of Inhibitors of $\mathrm{N}$-assimilation and comparison with ammonium. Plant Sci. 93, 77-84. doi: 10.1016/01689452(93)90036-Y

Schulze, E. D., and Bloom, A. J. (1984). Relationship between mineral nitrogen influx and transpiration in radish and tomato. Plant Physiol. 76, 827828. doi: 10.1104/pp.76.3.827

Shaner, D., and Boyer, J. S. (1975). Relationship between nitrate supplied by transpiration stream and nitrate reductase-activity in maize leaves. Plant Physiol. 56, 61-61.

Sicher, R. C. (2008). Effects of $\mathrm{CO} 2$ enrichment on soluble amino acids and organic acids in barley primary leaves as a function of age, photoperiod and chlorosis. Plant Sci. 174, 576-582. doi: 10.1016/j.plantsci. 2008.03.001

Simonneau, T., Barrieu, P., and Tardieu, F. (1998). Accumulation rate of ABA in detached maize roots correlates with root water potential regardless of age and branching order. Plant Cell Environ. 21, 1113-1122. doi: 10.1046/j.1365-3040.1998.00344.x

Sprent, J. I., and Thomas, R. J. (1984). Nitrogen nutrition of seedling grain legumes - some taxonomic, morphological and physiological constraints. Plant Cell Environ. 7, 637-645. doi: 10.1111/1365-3040.ep11571523

Takei, K., Sakakibara, H., Taniguchi, M., and Sugiyama, T. (2001) Nitrogen-dependent accumulation of cytokinins in root and the translocation to leaf: implication of cytokinin species that induces gene expression of maize response regulator. Plant Cell Physiol. 42, 85-93. doi: 10.1093/pcp/pce009

Takei, K., Takahashi, T., Sugiyama, T., Yamaya, T., and Sakakibara, H. (2002). Multiple routes communicating nitrogen availability from roots to 
shoots: a signal transduction pathway mediated by cytokinin. J. Exp. Bot. 53, 971-977. doi: 10.1093/jexbot/53. 370.971

Tardieu, F., and Davies, W. J. (1993). Integration of hydraulic and chemical signaling in the control of stomatal conductance and water status of droughted plants. Plant Cell Environ. 16, 341-349. doi: 10.1111/j.13653040.1993.tb00880.x

Teng, N. J., Wang, J., Chen, T., Wu, X. Q., Wang, Y. H., and Lin, J. X. (2006). Elevated CO2 induces physiological, biochemical and structural changes in leaves of Arabidopsis thaliana. New Phytol. 172, 92 103. doi: $10.1111 / \mathrm{j} .1469-8137.2006$. 01818.x

Tian, Q., Chen, F., Liu, J., Zhang, F., and Mi, G. (2008). Inhibition of maize root growth by high nitrate supply is correlated with reduced IAA levels in roots. J. Plant Physiol. 165, 942-951. doi: 10.1016/j.jplph.2007. 02.011

Tillard, P., Passama, L., and Gojon, A. (1998). Are phloem amino acids involved in the shoot to root control of NO3- uptake in Ricinus communis plants? J. Exp. Bot. 49, 1371-1379. doi: 10.1093/jexbot/49. 325.1371

van Bel, A. J. E. (2003). The phloem, a miracle of ingenuity. Plant Cell Environ. 26, 125-149. doi: 10.1046/j.1365-3040.2003.00963.x

Vernieri, P., Lenzi, A., Figaro, M., Tognoni, F., and Pardossi, A. (2001). How the roots contribute to the ability of Phaseolus vulgaris L. to cope with chilling-induced water stress. $J$. Exp. Bot. 52, 2199-2206.
Very, A. A., Robinson, M. F., Mansfield, T. A., and Sanders, D. (1998). Guard cell cation channels are involved in $\mathrm{Na}+$-induced stomatal closure in a halophyte. Plant J. 14, 509521. doi: 10.1046/j.1365-313X.1998. 00147.x

Walch-Liu, P., Ivanov, Ii, Filleur, S., Gan, Y., Remans, T., and Forde, B. G. (2006). Nitrogen regulation of root branching. Ann. Bot. 97, 875-881. doi: 10.1093/aob/mcj601

Walch-Liu, P., Neumann, G., Bangerth, F., and Engels, C. (2000). Rapid effects of nitrogen form on leaf morphogenesis in tobacco. J. Exp. Bot. 51, 227-237. doi: 10.1093/jexbot/51. 343.227

Wang, Y., Du, S. T., Li, L. L. Huang, L. D., Fang, P., Lin, X. Y., et al. (2009). Effect of CO2 elevation on root growth and its relationship with indole acetic acid and ethylene in tomato seedlings. Pedosphere 19, 570-576. doi: 10.1016/S10020160(09)60151-X

Warren, J. M., Norby, R. J., and Wullschleger, S. D. (2011). Elevated $\mathrm{CO} 2$ enhances leaf senescence during extreme drought in a temperate forest. Tree Physiol. 31, 117-130. doi: 10.1093/treephys/tpr002

Werner, T., Holst, K., Pors, Y., Guivarc'h, A., Mustroph, A., Chriqui, D., et al. (2008). Cytokinin deficiency causes distinct changes of sink and source parameters in tobacco shoots and roots. J. Exp. Bot. 59, 2659-2672. doi: 10.1093/jxb/ern134

Whorf, T., and Keeling, C. D. (1998). Rising carbon. New Sci. 157, 54.

Wilkinson, S., Bacon, M. A., and Davies, W. J. (2007). Nitrate signalling to stomata and growing leaves: interactions with soil drying, $\mathrm{ABA}$, and xylem sap $\mathrm{pH}$ in maize. $J$. Exp. Bot. 58, 1705-1716. doi: 10.1093/jxb/erm021

Wilkinson, S., and Davies, W. J. (2002). ABA-based chemical signalling: the co-ordination of responses to stress in plants. Plant Cell Environ. 25, 195-210. doi: 10.1046/j.0016 8025.2001.00824.x

Xiao, C. W., Sun, O. J., Zhou, G. S., Zhao, J. Z., and Wu, G. (2005). Interactive effects of elevated $\mathrm{CO}_{2}$ and drought stress on leaf water potential and growth in Caragana intermedia. Trees 19, 711-720. doi: 10.1007/s00468005-0435-2

Yong, J. W. H., Wong, S. C., Letham, D. S., Hocart, C. H., and Farquhar, G. D. (2000). Effects of elevated $\left[\mathrm{CO}_{2}\right]$ and nitrogen nutrition on cytokinins in the xylem sap and leaves of cotton. Plant Physiol. 124, 767-779. doi: 10.1104/pp.124. 2.767

Zhang, H., Rong, H., and Pilbeam, D. (2007). Signalling mechanisms underlying the morphological responses of the root system to nitrogen in Arabidopsis thaliana. J. Exp. Bot. 58, 2329-2338. doi: 10.1093/jxb/ erm 114

Zhang, J., and Davies, W. J. (1989). Abscisic-acid produced in dehydrating roots may enable the plant to measure the water status of the soil. Plant Cell Environ. 12, 73 81. doi: 10.1111/j.1365-3040.1989. tb01918.x

Zhang, S. Q., and Outlaw, W. H. (2001). Abscisic acid introduced into the transpiration stream accumulates in the guard-cell apoplast and causes stomatal closure. Plant Cell Environ. 24, 1045-1054. doi: 10.1046/j.13653040.2001.00755.x

Zheng, Z. L. (2009). Carbon and nitrogen nutrient balance signaling in plants. Plant Signal. Behav. 4, 584-591. doi: 10.4161/psb.4.7. 8540

Conflict of Interest Statement: The authors declare that the research was conducted in the absence of any commercial or financial relationships that could be construed as a potential conflict of interest.

Received: 15 March 2013; accepted: 22 July 2013; published online: 09 August 2013.

Citation: Easlon HM and Bloom AJ (2013) The effects of rising atmospheric carbon dioxide on shoot-root nitrogen and water signaling. Front. Plant Sci. 4:304. doi: 10.3389/fpls.2013. 00304

This article was submitted to Frontiers in Functional Plant Ecology, a specialty of Frontiers in Plant Science.

Copyright: (c) 2013 Easlon and Bloom. This is an open-access article distributed under the terms of the Creative Commons Attribution License (CC BY). The use, distribution or reproduction in other forums is permitted, provided the original author(s) or licensor are credited and that the original publication in this journal is cited, in accordance with accepted academic practice. No use, distribution or reproduction is permitted which does not comply with these terms. 